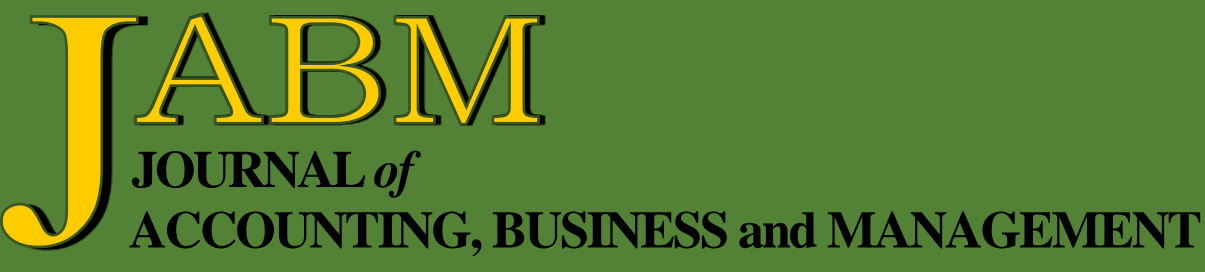

Towards Understanding the Effects of Web 2.0 at the Project Level Knowledge Management on Projects' Success

Anupam Kumar Nath

Sticky Costs and Expenses are not Alike: Mexican Reality

Luis Felipe Llanos Reynoso, César Vela-Beltrán-del-Río, and

José Luis Martínez-Berrones

Business Sustainability Through Environmental and Operational Management in Five Star Hotels in Amman, Jordan

Haitham Abdelrazaq, Taghreed Aljaffal, Pheroza Daruwalla, and

Karina Wardle

Impacts of Asset Utilization, Market Competition and Market

Distance on Stock Returns

Jeanne-Claire Patin, Matiur Rahman, and Muhammad Mustafa

Accounting Conservatism, Information Asymmetry and

Cash Holdings

Walid Shehata and Ahmed Rashed

An Investigation of the Relationship between Corporate Social Responsibility and Corporate Financial Performance in Egypt: The Mediating Role of Information Asymmetry

Nancy Mohamed and Ahmed Rashed

The Impact of Regulatory Capital and Bank Characteristics on the Relationship between Bank Competition and Risk Taking in the Banking System

Eman Abdel-Wanis

Firm Size, Firm Age, and Firm Profitability: Evidence from China Md. Jahidur Rahman and Liu Yilun 
Journal of Accounting, Business and Management vol. 28 no. 1 (2021) 87-100

\title{
The Impact of Regulatory Capital and Bank Characteristics on the Relationship between Bank Competition and Risk Taking in the Banking System
}

\author{
Eman Abdel-Wanis*
}

\begin{abstract}
This paper explores the association between bank competition, regulatory capital, and bank risk taking in an Egyptian setting and to examine the interaction between bank competition and regulatory capital and their impact on bank risk taking in developing countries like Egypt and also investigate the effect of bank characteristics on the relationship between bank competition and bank risk taking through a sample of 27 Egyptian listed banks during the period 2012-2018 using OLS regression . Results indicated that there is a negative impact of bank competition on the bank risk taking and a positive effect of regulatory capital on bank risk taking in the Egyptian listed banks. Results show that increase regulatory play a vertical role in enhance association between competition and bank risk taking and also, there is a positive impact of bank characteristics like: bank size and divarication on bank risk taking in the Egyptian banks. Results refer to there is no effect of bank type, leverage and profitability to support the relationship between bank competition and risk taking.
\end{abstract}

Keywords: regulatory capital, bank characteristics, bank competition, and risk taking.

\section{INTRODUCTION}

Recent studies indicated the role of Financial institutions monitor monetary transactions effectively, which have a positive effect on the economy and overall financial stability, which banking sector is facing financial and economic challenges.

To enhance to financial stability, Egypt's Central Bank has begun to implement certain laws and programs to attain sustainable economic industry development. The first reform program took place in 2004 and ended in 2008, followed by a second reform program in 2009, completed in 2011 and expanded for a further three months, with the aim of applying Basel II laws in the banking sector in Egypt, which was applied with the European Union's assistance. Basel II's primary objective is to enhance the methods of risk management that will lead to economic stability and effective capital management. The required Minimum capital adequacy ratios is $10 \%$ (i.e. tier1+tier2)/risk weighted assets.

Noss and Toffano (2016) have argued that there has been a need to develop international financial regulations because of international economic crises and other pressing financial issues which would seem to apply Basel III in some countries during the last couple of years. The aim of Basel III is to improve the quality of capital that will enable banks to absorb more losses.

Poshakwale and Qian (2011) have proven that the financial adjustments improve the competitiveness of the banking sector which contributes to better economic growth. Moreover, the global financial and economic crises, especially the 2007-2008 crisis, which had negative impact at the global level, which led to many banking failures,

\footnotetext{
* Accounting and Finance Department, Faculty of Commerce, Cairo University, Cairo, Egypt. E-mail: eman_m_abdelwanis@foc.cu.edu.eg.
} 
has shed the light on the importance of managing bank risk taking. It was important to adopt and apply efficient and effective approaches to predict and mitigate the default risk of banks and achieve financial stability. Additionally, Luca and Olivero (2012) have clarified the impact of currency crisis on the banking system and have argued that because of devaluation, there has been more dependence on bank credit leading to contracting influences on the country's economy. To resolve this issue, policy makers should set careful regulatory guidelines before the process of devaluation to reinforce the capital market.

Banks have higher risk (default risk) when they face difficulties while paying their financial obligations. This means that the value of bank deposits and its liabilities exceed the value of its assets, banks will face problems while paying creditors on due time (Kaufman, 2014).

Huang and Lee (2013) have argued that, it has been important to consider the market power and competition. Also, Anginer and Demirguc-Kunt (2014) have investigated the influence of global trends on default risk on banks in 65 countries, showing that default risk has increased in countries that adopted liberalized financial systems. They have suggested that risk can be reduced through efficient monitoring policies and supervision on banks. Moreover, at the European level, Fiordelisi and Marqués-Ibañez (2013) have added that the increase in default risk can have a negative impact at both the European banking sector (systematic risk) and the overall financial system and non-financial institutions.

There has been ongoing debate regarding whether bank competition increases or decreases bank risk taking behavior. There have been mixed results in the literature regarding this issue, depending on using different measures, different samples from around the world, different time periods. The first point of view is on competition fragility; which means higher competition will lead banks to engage in more risky activities that will negatively impact the financial stability. The second point of view is on competition stability; which means that higher competition will not lead banks to engage in risky activities, and that will lead to more financial stability. The objective of proposed study is to examine the following question, whether competition improves or deteriorates financial stability?

There has been another debate regarding whether regulatory capital increases or decreases bank risk taking behavior. There have been mixed results in the literature regarding this issue, also depending on different measures and different regulations. The first point of view shows that a capital standard is indirectly proportionate with the bank risk taking. The second point of view differs from the first point of view, as it shows that capital is directly proportionate with bank risk taking. Another research objective is to investigate whether regulatory capital increases or decreases bank risk taking?

The main contribution and objective of proposed study is to explore the association between bank competition, regulatory capital, and bank risk taking in an Egyptian setting and to examine the interaction between bank competition and regulatory capital and their impact on bank risk taking in developing countries like Egypt, which was rarely done in prior literature and explore the bank characteristics on the relationship between bank competition and bank risk taking in Egyptian listed banks. This paper is organized into five sections including this section. Section 2 presents the literature review from both regulatory capital, Bank competition and bank risk taking then section 3 present research methodology about sample, research model 
with measurements and section 4 conducting the empirical results, finally s discussion in depth in empirical results.

\section{LITERATURE REVIEW}

\subsection{Regulatory Capital and Bank Risk Taking}

According to a comparative theoretical paper by $\mathrm{Li}$ (2017) that has examined the association between capital regulation and risk taking of banks and by analyzing three different accounting models historical cost accounting, lower of cost or market accounting and fair value accounting, the analysis has claimed that lower cost or market accounting has been the most accurate method to measure the capital policies and regulations in which banks will hold more capital above the minimum requirements and at the same time engage in less risks.

To examine the association between applying international capital requirements and bank risk, Belanes and Hajiba (2012) have shown how the application of international standards of capital requirements in 1999 in Tunisian banks helped them in reducing the default risk which has resulted in banking stability. They also have added that large banks engage in more risk as driven by market.

A theoretical paper conducted by VanHoose (2007) who has noted that whenever there are constrains in capital there will also be constraints on lending, but on the long term there has been another agreement that such constraints put on capital will increase the capital ratios in banks and enable the banks to absorb any incurred losses or banks failures, hence protecting the depositors.

At a practical level, Noss and Toffano (2016) have emphasized that there has been a negative association between bank capital and lending, meaning that whenever there is an increase in capital there will be a decrease in lending and that will affect the lending growth negatively even on a short-term basis.

On the contrary, Francis and Osborne (2012) have endorsed that the association between bank capital and bank lending and growth of assets is directly proportionate based on 150 United Kingdom banks, which means enhancing capital standards in banks will lead to increase in lending and vice versa. Also, results have shown that banks enhance the ratio of capital by increasing low quality and cheap capital to reduce its cost and meet the regulatory standards, they also added that some banks adjust the risk weighting of their assets to lower it instead of modifying their volume of loans and portfolio of their assets.

Moreover, Shim (2013) has examined the association between regulatory capital and risk taking in the United States during the period of 1992-2011, has claimed that the association between them is indirectly proportionate; meaning that whenever the capital buffer increases in banking sector the default risk decreases which helps in improving the performance of the economy especially during the recession periods.

Also, at the European level, Chiaramonte and Casu (2016) have proven while studying European banks from the period of 2004-2013 that the default risk of banks decreases whenever capital increases resulting in banking stability. Consistent with the previous studies, Vazquez and Federico (2015) have emphasized the importance of capital buffer based on a sample from United States and European banks from 2001 till 2009, and add that large banks face more default risk when they have insufficient capital, thus it is important for such banks that their capital to be in line with their risk.

On the contrary, Linsmeier (2011) has argued that many banks in United States failed and there was a financial distress although they were well capitalized and hold sufficient capital as required by regulators, this means that there is a positive association 
between regulatory capital and bank risk. Also Abou-El-Sood (2016) has proven that regulatory capital leads to fragility in banks that owns below $6 \%$ capital based on a sample of 560 bank holding companies in United States covering the period 2003-2009, hence capital is not the only reason behind banking fragility, but improving the quantity and quality of capital can lead to improving the performance of banks, and this supports the results found in the aforementioned study that has proved that banks use cheapest types of capital in order to meet the regulatory standards (Francis and Osborne, 2012).

Ayaydin and Karakaya (2014) have presented and supported the findings of the two hypotheses; the first one is regulatory hypothesis that has tackled the positive association between capital and risk, whenever banks engage in more risky activities, they increase their capital reserves and the other hypothesis is moral hazard hypothesis which has stated that when banks engage in more risky activities or encounter any problems, they might use their capital reserves based on a sample from Turkish banks from the period of 2003-2011.

A comparative study that has been presented by Jonghe and Öztekin (2015) covering the period from 1994-2010 on 64 countries, has suggested that banks in countries with well-functioning capital market and that adopt effective tools and mechanisms of supervision and good monitory policies, will apply adjustments and modifications on capital structure, also quick adjustments on capital structure can be made in times of economic crises. Also, Berger et al. (2008) have argued that the reasons behind holding excess capital in United States from 1992 till 2006 than the requirements of regulators are: retained earnings, more open to default risk, to protect their profits on the long run, and finally it is regarded as a reserve for any future investments and they have also added that adjustments in capital are made quicker with banks who have poor capital.

However, Guidara et al. (2013) have reported that there has been no association between capital and risk on the Canadian banking sector based on the data collected from 1982 to 2010. Although capital buffer in the Canadian banks were very good, the indication showed that it might have been the result of market power in Canada.

Based on the proposed literature, most studies have proven negative association between regulatory capital and bank risk taking. Few studies have shown that there has been a positive association between regulatory capital and bank risk, thus this issue is still ambiguous. It has also been noted that other factors have an influence on the findings to examine the association between the two variables, such as the size of banks and the regulations applied in different countries. In addition, a large number of studies presented in the above literature claim an indirect association between regulatory capital and bank risk, meaning that there is a statistical significance relationship between the two variables (Belanes \& Hajiba, 2012; Shim, 2013; and Chiaramonte \& Casu, 2016) thus the second hypothesis will be as follows:

$\mathbf{H}_{1}$ : there is a significant association between regulatory capital and bank risk taking.

\subsection{Bank Competition and Bank Risk Taking}

Concerning the competition fragility point of view, Jiang et al. (2017) have examined the association between bank competition and risk in the United States banks and the findings have proven that bank competition has strengthened level of default risk as long as banks had low profits, had declined charter value, their dependence on in-common services and their drop in the lending relationship. Depending on a sample from United States in the period within 1996 until 2012, Bushman et al. (2016) have 
concluded that the default risk as well as the overall risk of the system increase because of high level of bank competition as it will cause deterioration on the long run on bank's loan portfolio which will have a negative impact on the credit quality as well as the stability of the bank.

While examining Russian banks within 2001-2007, Fungacova and Weill (2013) have confirmed that high bank competition has harmed financial stability. At the European level, Cipollini and Fiordelisi (2012) have examined this association from 1996-2009 based on a sample of 308 European commercial banks, and the study has implied that banks have engaged in more risky projects during periods of high level of competition, leading to financial destabilization in order to earn more profit. This is compatible with the findings by Berger et al. (2009) who have endorsed that in case banks have elevated franchise value that comes from their market power, risk mitigating techniques and more capital can assist in reducing the overall risk.

Moreover, Fernández et al. (2016) have also added that high competition causes decline in both banking stability and economic volatility. This finding was reached by examining 110 banks in developed and developing countries as a sample covering the period between 1989 and 2008. In contrast, Fiordelisi and Mare (2014) have proven that high competition leads to lower risk, thereby high financial stability.

To assess the association regarding deposits, engineer et al. (2013) have executed a theoretical paper and have argued that it has been a national objective to encourage depositors through attractive rates, costs and insurance in order to maintain a stabilized banking system. An empirical study by Craig and Dinger (2013) in the United States, covering the period of 1997-2006, has proved that higher competition will lead to higher deposits rates, which will burden the banks with more liabilities, and accordingly the risk increase. On the other hand, Akins et al. (2016) have found that enhancing competition will result in less interest margins and more engagement in lower risk investments in United States banks, so there will be low probability of bank failure accompanied with financial stability.

Concerning competition stabilizing point of view, Soedarmonoa et al. (2013) have argued that lower degree of competition in the banking sector will related to more tendency for banks to default, which has a negative influence on the financial stability depending on a sample of commercial banks in Asia during the period of 1994-2009. In consistency with the previous studies, Chong et al. (2013) while studying the effect of banking competition on SMEs credit in China using stratified survey. They have proven that SMEs have less probability of facing credit limitations during banking competition.

While examining the Spanish banking sector, Jiméneza et al. (2013) have concluded that to maintain the franchise value of the banking system, there should be more market power and less competition in the market of loans to reduce their exposure to default risk and therefore increasing the tendency of stability of the Spanish banking sector. On the contrary, Sarkar and Sensarma (2016) have examined this association in India during the period 1999-2013. They have been able to prove that the higher the competition is in the loan market, the lower the interest rate on loans, and therefore, low default risk and high stability which has implied that borrowers suffer from lower difficulties during repayments. Also, Fungácová et al. (2014) have stressed on the usefulness of competition in relation to the monetary policy through the bank lending channel for central banks, a matter that has caused the banks to actively respond to monetary policy as it has proved that competition declines the use of other options of funding. 
A comparative study between Islamic and conventional banks by Al-Tamimi and Jellali (2013) has clarified that Islamic banks are not open to risk taking unlike the conventional ones and has proven that regarding the conventional banks as long as there is lower competition, there will be lower risk as well as financial stability. The sample has been comprised from fifteen national banks in which eleven have been conventional banks and the other four have been Islamic in the United Arab Emirates from 1998-2010. Another classification by Mulyaningsih et al. (2015) has shown that international banks are more likely to compete compared with the local ones in Indonesia from 1980 to 2010.

In Japan, Liu and Wilson (2013) have declared a difference in the tendency of credit banks and city banks in risk taking and have concluded that credit banks are more likely to engage in risks in case of high competition than city banks, which will strive to preserve their franchise value. In line with the previous studies, Huang and Lee (2013) have asserted that smaller firms are more likely to default than larger ones, which has a positive association with the concentration ratio.

In Kenya, Mwega (2011) has reported that Kenyan medium banks during the period of 1998-2007 have been more competitive and large banks have been more competitive than small banks, which accordingly, has proved banks size has an influence on this association.

Saif-Alyousfi et al. (2018) explore the relationship between competition and bank risk taking in the Gulf Cooperation Council (GCC) banking market during the period 1998-2016. Our results show that decrease level of bank competition in the GCC banking increase the risk-taking behavior and the greater degree of concentration adds to financial fragility.

Phan et al. (2019) investigate the association between competition, efficiency and stability during the period between 2004-2014 in East Asian countries. The results enhance the competition-fragility view a, which argued that a higher degree of competition may result in a lower in bank credit risk.

Based on the proposed literature, there is still a debate whether bank competition increases or decreases bank risk taking and how it impacts the financial stability. However, many studies have shown that there has been a positive association between bank competition and bank risk that causes deterioration in bank stability, while other studies have shown that there has been a negative association between the two variables. It is also noted that types and sizes of banks have a major influence on the association between bank competition and risk.

Majority of studies presented in the literature review show the direct association between bank competition and bank risk, meaning that there is a statistical significance relationship between the two variables (Fungacova \& Weill, 2013; Bushman et al. 2016; Fernández et al. 2016; and Jiang et al. 2017), accordingly the first hypothesis will be stated as follows:

$\mathbf{H}_{2}$ : there is a significant association between bank competition and bank risk taking.

Some studies that have tackled the asscociation between bank competition and bank risk taking have used regulatory capital as a control variable, results have shown that in case of bank competition, banks have higher risk especially if they suffer from decline in their capital. They also added that the exposure of banks to risk can be mitigated through increasing their capital ratios. Accordingly, regulators of banks must focus on the importance of capital requirements to absorb losses and face the risk of banks (Berger et al. 2009; Cipollini \& Fiordelisi, 2012; and Bushman et al. 2016). Accordingly the third hypothesis can be stated as follows: 
$\mathbf{H}_{3}$ : the association between bank competition and bank risk taking is attenuated for banks with larger regulatory capital.

$\mathbf{H}_{4}$ : the association between bank competition and bank risk taking is attenuated for banks with bank characteristics.

\section{RESEARCH SAMPLE AND METHODOLOGY}

The study conducted among 27 banks registered in the Central Bank of Egypt covering the period from 2012 till 2018. Data collected from the banks registered in the Central bank of Egypt depending on secondary data through the annual financial stataments. Also, the researcher used Bankscope database to get the required data.

The main aim of the model is to nbvdq1 clarify the relationship between variables. Whereby the formula is as follows:

$$
\begin{aligned}
\mathrm{RT}_{\mathrm{it}}= & \alpha+\beta_{1} \mathrm{BC}_{\mathrm{it}}+\beta_{2} \mathrm{RC}_{\mathrm{it}}+\beta_{3} \mathrm{RC}_{\mathrm{it}} * \mathrm{BC}_{\mathrm{it}}+\beta_{4} \mathrm{Size}_{\mathrm{it}}+\beta_{5} \text { lev }+\beta_{6} \text { Prof }+ \\
& \beta_{7} \text { Dive }+\beta_{8} \mathrm{BT}+\beta_{9} \mathrm{BC}_{\mathrm{it}} * \mathrm{Size}_{\mathrm{it}}+\beta_{10} \mathrm{BC}_{\mathrm{it}} * \text { lev }+\beta_{11} \mathrm{BC} \mathrm{C}_{\mathrm{it}} * \text { Prof }+ \\
& \beta_{12} \mathrm{BC}_{\mathrm{it}} * \text { Dive }+\beta_{13} \mathrm{BC}_{\mathrm{it}} * \mathrm{BT}+\varepsilon_{\mathrm{it}} \ldots \ldots \ldots \ldots \ldots \ldots \ldots \ldots \ldots \ldots
\end{aligned}
$$

Risk taking (RT) measured by simplified Z-score is calculated as: $\frac{R O A+{ }^{T E} / T A}{\sigma R O A}$, Z-score measured by the sum of bank's return on assets and equity to assets ratio divided by the standard deviation of return on assets. Z-score is a common measure for default risk (bank risk) depending on a sample from United States banks from 20042012; as it can predict failure three years in advance which is a sufficient period. In addition, previous studies have shown that higher values of Z-score indicates low default risk (low bank risk) and more banking stability, this measure is also used by (Bushman et al. 2016; Fernández et al. 2016; Fiordelisi and Mare, 2014; Vazquez and Federico, 2015).

To measure bank competition (BC) , Bushman et al. (2016) have suggested a Herfindahl-Hirschman concentration ratio using bank deposits, it is computed for each bank's year as: bank's deposits in a year divided by total deposits of all banks in the same year, also Herfindahl-Hirschman concentration used by (Fungacova \& Weill, 2013; Sarkar \& Sensarma, 2016).

\section{Herfindahl-Hirschman concentration \\ Total deposits in each bank in a year

To measure regulatory capital (second independent variable), some studies have used a good proxy for determining capital position of banks which is the total regulatory capital ratio (total risk based capital ratio) which is equal to regulatory capital (the sum of tier 1 and tier 2 capital) divided by risk weighted assets (Berger et al. 2008; Chernykh and Cole, 2015; and Chiaramonte and Casu, 2016). However, other studies have argued that tier 1 is the core capital that constitutes accounting equity and some regulatory adjustments, they also added that nature of tier 1 capital strengthens the idea of having enough capital in banks to face bank risk taking and absorb losses, so it is considered as a good and efficient measurement to predict bank risk (default risk). Accordingly, tier 1 capital divided by ratio of risk weighted assets have been used as a proxy for regulatory capital by (Berger et al., 2008; Jonghe \& Öztekin, 2015; Vazquez \& Federico, 2015; Abou-El-Sood, 2016; and Chiaramonte \& Casu, 2016).

$$
\text { Hence, regulatory capital }=\frac{\text { Tier 1+Tier } 2}{\text { Risk Weighted Assets }} \text { or } \frac{\text { Tier } 1}{\text { Risk Weighted Assets } \ldots}
$$

Tier 1: is a core capital includes which includes common equity, retained earnings, surplus, reserves, non cumulative perpetual preferred stock, minority interest, and other regulatory adjustments such as deducting goodwill. Tier 2: is a supplemental capital which includes allowance for loan losses up to $1.25 \%$ of risk weighted assets, 
subordinated debt other instruments and regulatory adjustments. Risk weighted assets: which means allocating various weights to the assets of banks and off balance sheet items to cover various sort of bank risk taking such as: credit risk, market risk and operational risk (Francis \& Osborne, 2012; Chernykh \& Cole, 2015; Abou-El-Sood, 2016; and Li, 2017).

According to the literature, bank characteristivs like: bank size has proved that it has an influence on bank risk taking (Mwega, 2011; Huang \& Lee, 2013; and Vazquez $\&$ Federico, 2015). Concerning the control variable, banks size has been measured as the natural logarithm of total assets by (Soedarmonoa et al., 2013; Bushman et al., 2016; and Sarkar and Sensarma, 2016). Leverage measured by total debt scaled by total assets profitability measured by net income scaled by total assets and bank diversiication measure by the ratio of non- interst income to total operating income, finally measured bank type is a dummy variable: zero represent as a private banks and one represent a public banks.

\section{EMPIRICAL RESULTS}

\subsection{Classification of All Banks Include}

\section{Table1}

Frequency of Bank Type (BT)

\begin{tabular}{ccc}
\hline Type & Frequence & Percent \\
\hline Private Banks & 154 & 81.48 \\
Public Banks & 35 & 18.52 \\
\hline
\end{tabular}

This Table 1 shows that private banks represent $81.5 \%$ approximately of all sample included whenever public banks formelt $18.5 \%$ of all banks.

\subsection{Descriptive Statistics}

Table 2 explains the properties of the all study variables through the period between 2012 to 2018 for 27 Egyptian banks.

\section{Table 2}

\section{Descriptive Statistics}

\begin{tabular}{lccccc}
\hline Variable & Obs. & Mean & Std. & Min. & Max. \\
\hline Z-score & 189 & 3.367 & 1.241 & 0 & 6.519 \\
RC & 189 & .162 & .059 & .074 & .486 \\
BC & 189 & .009 & .114 & -.267 & 1.164 \\
Size & 189 & 24.073 & 1.078 & 22.228 & 27.279 \\
Prof & 189 & .014 & .013 & -.06 & .112 \\
Lev & 189 & .897 & .042 & .748 & .961 \\
Dive & 189 & .282 & .124 & -.037 & .879 \\
\hline
\end{tabular}

The descriptive statistics of risk taking (Z-score) shows that the majority of the Egyptian banks are higher risk taking with a low variation of $Z$-score across banks. Also, the mean value of regulatory capital (RC) is $(0.162)$ which means that on average the banks in the sample make high regulatory capital. This table shows that the mean value of bank competition (BC) is (0.009) which means that there is a high variation of bank competition across the banks. Moreover, the descriptive analysis of the bank characteristics (moderation): Size, Prof, Lev, Dive show a mean value are (24.073, $0.014,0.897,0.282)$ with a standard deviation are $(1.078,0.013,0.042,0.124)$ respectively which means that all bank characteristics are low variation across the banks. 


\subsection{Correlation Matrix}

Table 3

Pairwise Correlations

\begin{tabular}{llllllll}
\hline Variables & \multicolumn{1}{c}{$\mathbf{1}$} & \multicolumn{1}{c}{$\mathbf{2}$} & $\mathbf{3}$ & $\mathbf{4}$ & $\mathbf{5}$ & $\mathbf{6}$ & $\mathbf{7}$ \\
\hline 1. Z-score & 1.000 & & & & & & \\
2. RC & $.230^{*}$ & 1.000 & & & & & \\
& .001 & & & & & & \\
3. BC & $.162^{*}$ & -.059 & 1.000 & & & & \\
& .026 & .421 & & & & & \\
4. Size & .059 & $-.525^{*}$ & -.051 & 1.000 & & & \\
& .420 & .000 & .483 & & & & \\
5. Prof & .111 & -.070 & -.040 & $.206^{*}$ & 1.000 & & \\
& .128 & .341 & .589 & .005 & & & \\
6. Lev & $-.348^{*}$ & $-.497^{*}$ & $-.206^{*}$ & $.468^{*}$ & $-.243^{*}$ & 1.000 & \\
& .000 & .000 & .004 & .000 & .001 & & \\
7. Dive & $.392^{*}$ & -.054 & $.200^{*}$ & -.043 & .022 & $-.263^{*}$ & 1.000 \\
& .000 & .461 & .006 & .552 & .762 & .000 & \\
\hline
\end{tabular}

Note: * shows significance at the $.05(5 \%)$ level.

Table 3 shows that there is a significant positive correlation between regulatory capital and risk taking. This means that risk taking increases regulatory capital. Also, there is a positive correlation between bank competition and risk taking. This means that risk taking increases bank competition. Concerning the bank characteristics variables, the results show there is no relationship between for both bank size, profitability and risk taking but there is a negative relationship between leverage and risk taking whenever there is a positive relationship between diversification and risk taking.

\subsection{Diagnostics Tests}

Table 4

Diagnostics Tests

\begin{tabular}{lll}
\hline \multicolumn{1}{c}{ Diagnostics Tests } & \multicolumn{1}{c}{ Results } & \multicolumn{1}{c}{ Probabilities } \\
\hline 1. Heteroskedasticity & Chi2 $(1)=1.93$ & Prob. $>$ Chi2 $=0.1648$ \\
2. Omitted variable & F $(3,177)=2.63$ & Prob. $>\mathrm{F}=0.06$ \\
3. Unit Root & F-statistic $=-84.388$ & Prob. F $=0.000$ \\
4. Serial Correlation & F-statistic $=2.123$ & Prob. $F=0.188$ \\
5. Co-integration & Dickey-Fuller statistic $=-2.278$ & Prob. $=0.000$ \\
\hline
\end{tabular}

Table 4 show that the chi-square is (1.93). The value of probability is higher than (0.05) therefore there is a homoscedasticity among all variables. Omitted variable show that the probability of F-test (2.63) which are higher than (0.05) therefore there is no omitted variable between error and independent variable. Unit root shows the P-value of LLC is less than (0.05). This means that all variables in the current research have stationary time series. The probability of F-test is higher than (0.05). Thus, there is no serial correlation between independent and dependent variables in both empirical models. This means that the results of the current research will be correct, and conclusions will not be biased. According to the P-value of Kao test. Almost the whole variables are significant. Thus, there are long-term equilibrium relationships among variables. 


\subsection{OLS Regression}

\section{Table 5}

\section{OLS Regression}

\begin{tabular}{|c|c|c|c|c|c|c|c|}
\hline Z-score & Coef. & St.Er & t-value & p-value & 95\% Conf. & Interval & Sig. \\
\hline RC & 7.435 & 1.698 & 4.38 & 0.000 & 4.084 & 10.787 & $* * *$ \\
\hline BC & -6.024 & 3.339 & -1.80 & 0.043 & -12.614 & 0.565 & ** \\
\hline RCBC & 50.573 & 24.158 & 2.09 & 0.038 & 2.903 & 98.242 & $* *$ \\
\hline Size & 0.418 & 0.096 & 4.34 & 0.000 & 0.228 & 0.608 & $* * *$ \\
\hline Prof & 0.168 & 5.970 & 0.03 & 0.978 & -11.612 & 11.949 & \\
\hline Lev & -7.620 & 2.590 & -2.94 & 0.004 & -12.732 & -2.509 & $* * *$ \\
\hline Dive & 3.560 & 0.656 & 5.43 & 0.000 & 2.266 & 4.853 & $* * *$ \\
\hline BT & 0.079 & 0.224 & 0.35 & 0.725 & -0.362 & 0.520 & \\
\hline Constant & -2.090 & 2.876 & -0.73 & 0.468 & -7.766 & 3.585 & \\
\hline \multicolumn{3}{|c|}{ Mean dependent var.: } & 3.367 & \multicolumn{2}{|c|}{ SD dependent var.: } & 1.241 & \\
\hline & \multirow{2}{*}{\multicolumn{2}{|c|}{$\begin{array}{r}\text { R-squared: } \\
\text { F-test: }\end{array}$}} & 0.346 & \multicolumn{2}{|c|}{ Number of obs.: } & 189.000 & \\
\hline & & & 11.915 & \multicolumn{2}{|c|}{ Prob. $>$ F: } & 0.000 & \\
\hline
\end{tabular}

Note: ${ }^{* * *} p<0.01,{ }^{* *} p<0.05$, and ${ }^{*} p<0.1$ (indicate significance at $1 \%, 5 \%$, and $10 \%$ levels).

The results refer to that the coefficient of regulatory capital is a positive and statistically significant at $1 \%$ level. This means that increase regulatory capital with high risk taking. Hence, the first hypothesis $\mathrm{H}_{1}$ is accepted. Moreover, the results show that there is a negative impact of bank competition on risk taking. Hence, the second hypothesis $\mathrm{H}_{2}$ is accepted. Results show that higher regulatory capital increae associatoon betwee bank competition and bank risk taking. Hence, the third hypothesis $\mathrm{H}_{3}$ is accepted. The results show that there is a positive impact of bank size, diversification on risk taking but there is a negative impact of leverage on risk taking. Also, the results refer to that there is no impact for both bank profitability and bank type (private or public) on risk taking. This model is significant and explain $34.6 \%$ of the variation in risk taking.

Table 6

The Moderaction Effect (Bank Chractersistics)

\begin{tabular}{lcccccc}
\hline \multicolumn{1}{c}{ Variable } & Model 1 & Model 2 & Model 3 & Model 4 & Model 5 & Model 6 \\
\hline RC & $7.44^{* * *}$ & $7.44^{* * *}$ & $7.74^{* * *}$ & $7.71^{* * *}$ & $7.39^{* * *}$ & $7.75^{* * *}$ \\
BC & -13.539 & -5.972 & 21.90 & $-13.35^{* *}$ & -6.36 & $-128.80^{*}$ \\
RCBC & $52.977^{*}$ & $51.46^{*}$ & $50.63^{*}$ & $69.49^{* *}$ & $55.38^{*}$ & $123.56^{* * *}$ \\
Size & $.4174^{* * *}$ & $.415^{* * *}$ & $.404^{* * *}$ & $.404^{* * *}$ & $.416^{* * *}$ & $.395^{* * *}$ \\
Prof & .19366 & .7515 & -.034 & 1.325 & .557 & 2.33 \\
Lev & $-7.59^{* *}$ & $-7.58^{* *}$ & $-7.04^{* *}$ & $-7.74^{* *}$ & $-7.32^{* *}$ & $-7.58^{* *}$ \\
Dive & $3.571^{* * *}$ & $3.54^{* * *}$ & $3.56^{* * *}$ & $3.397^{* * *}$ & $3.415^{* * *}$ & $3.136^{* * *}$ \\
BT & .0837 & .0849 & .081 & .144 & .0167 & .144 \\
Size*BC & .2993 & & & & & $3.414^{*}$ \\
Prof*BC & & -12.554 & & & & 29.320 \\
Lev*BC & & & $-32.83^{*}$ & & & 24.841 \\
Dive*BC & & & & $10.36^{* *}$ & & $21.451^{* *}$ \\
BT*BC & & & & & -2.98 & -5.27 \\
cons & -2.09 & -2.05 & -2.36 & -1.68 & -2.28 & -1.57 \\
r2 & .346 & .346 & .361 & .370 & .351 & .396 \\
r2_a & .313 & .313 & .329 & .338 & .3187 & .351 \\
Aic & 556.67 & 556.69 & 552.2 & 549.5 & 555.2 & 549.5 \\
Bic & 589.09 & 589.11 & 584.66 & 581.99 & 587.66 & 594.95 \\
Rmse & 1.028 & 1.028 & 1.016 & 1.009 & 1.024 & .9993 \\
\hline
\end{tabular}

Note: ${ }^{*} \mathrm{p}<0.05 ;{ }^{* *} \mathrm{p}<0.01 ;$ and ${ }^{* * *} \mathrm{p}<0.001$. 
According to model 6, the results show that the coefficient of bank competition is a negative and statistically significant at 5\% level. Also, the coefficient of bank size and diversification (Size $* \mathrm{BC}$, Dive $* \mathrm{BC}$ ) are a positive impact on the relationship between competition and risk taking at 1\%,5\% level respectively. The results refer to there is no impact for profiatability, leverage and bank type on the relationship between competition and risk taking. Hence, the fourth hypothesis $\mathrm{H}_{4}$ is accepted partially. Results show that the model 6 is a significant because of the significant value $(\mathrm{p}=$ 0.000 ) is less than (0.05). The value of $\mathrm{R}$ square is $39.6 \%$ (higher explanation between all models) which means that bank characteristics explain $39.6 \%$ on the relationship between bank competition and risk taking.

\section{CONCLUSION}

According to the effect of bank competition in Egyptian banks on the bank risk taking, the results showed that higher bank competition decrease risk taking which consist of many of studies like: Saif-Alyousfi et al. (2018) and Phan et al. (2019) but this result is not consistent with a majority of studies show there is a statistical significance positive relationship between bank competition and bank risk taking (Fungacova \& Weill, 2013; Bushman et al., 2016; Fernández et al., 2016; and Jiang et al., 2017).

Also, the results show the regulatory capital effects on the bank risk taking in the egyptian banks, this result enhanced the second hypothesis, which refers to that increase regualtory capital higher risk taking, which banks engage in more risky activities or encounter any problems. This results consist of many studies like : (Linsmeier, 2011; Francis \& Osborne, 2012; Ayaydin \& Karakaya , 2014; and Abou-ElSood, 2016) but this result isnot consistent with a large number of studies claim that there is a statistical significance negative relationship between regualtory capital and bank risk taking (Belanes \& Hajiba, 2012; Shim, 2013; and Chiaramonte \& Casu, 2016). Capital is not the only reason behind banking fragility but improving the quantity and quality of capital can lead to improving the performance of banks, and this supports the results have proved that banks use cheapest types of capital in order to meet the regulatory standards.

Results refer to increase regulatory capital enhance posirivelty the relationship between bank competition and bank risk taking so, the third hypothesis is accepted. They also added that the exposure of banks to risk can be mitigated through increasing their capital ratios. Accordingly, regulators of banks must focus on the importance of capital requirements to absorb losses and face the risk of banks (Berger et al., 2009; Cipollini \& Fiordelisi, 2012; and Bushman et al., 2016). According to the bank characteristics, the results showed that the fourth hypothesis is accepted which refers that for both bank size and diversification effects positively on the relationship between bank competition and bank risk. 
Table 7

Summary of the Hypotheses Testing Results

\begin{tabular}{|c|c|c|c|}
\hline Hypotheses Test & $\begin{array}{l}\text { Expected } \\
\text { Sign }\end{array}$ & Findings & $\begin{array}{r}\text { Accepted/ } \\
\text { Rejected }\end{array}$ \\
\hline $\begin{array}{l}\mathbf{H}_{1}: \text { regulatory capital effects on bank risk } \\
\text { taking }\end{array}$ & $+/-$ & + & Accepted \\
\hline $\begin{array}{l}\mathbf{H}_{2} \text { : bank competition effect on the bank } \\
\text { risk taking }\end{array}$ & $+/-$ & - & Accepted \\
\hline $\begin{array}{l}\mathbf{H}_{3} \text { : regulatory capital effects on the } \\
\text { relationship between bank } \\
\text { competition and bank risk taking }\end{array}$ & + & + & Accepted \\
\hline $\begin{array}{l}\mathbf{H}_{4} \text { : bank characteristics effects on the } \\
\text { relationship between bank } \\
\text { competition and bank risk taking }\end{array}$ & + & + & Accepted \\
\hline
\end{tabular}

\section{REFERENCES}

Abou-El-Sood, H. (2016). Are regulatory capital adequacy ratios good indicators of bank failure? Evidence from US banks. International Review of Financial Analysis, 48(C), 292-302.

Akins, B., Li, L., Ng, J., \& Rusticus, T. O. (2016 June). Bank competition and financial stability: Evidence from the financial crisis. Journal of Financial \& Quantitative Analysis, 51(1), 1-28.

Al-Tamimi, H. A. H., \& Jellali, N. (2013). The effects of ownership structure and competition on risk-taking behavior: Evidence from UAE conventional and Islamic banks. The International Journal of Business \& Finance Research, 7(2), 115-124.

Anginer, D., \& Demirguc-Kunt, A. (2014, August). Has the global banking system become more fragile over time? Journal of Financial Stability, 13, 202-213.

Ayaydin, H., \& Karakaya, A. (2014). The effect of bank capital on profitability and risk in Turkish banking. International Journal of Business \& Social Science, 5(1), 252-271.

Belanes, A., \& Hajiba, A. B. (2012, April). Regulation and risk-taking in the banking industry: Evidence from Tunisia. Afro-Asian Journal of Finance \& Accounting, 3(1), 89-104.

Berger, A. N., DeYoung, R., Flannery, M. J., \& Lee, D. K., \& Öztekin, Ö. (2008.). How do large banking organizations manage their capital ratios? Journal of Financial Services Research, 34(2-3), 123-149.

Berger, A. N., Klapper, L. F., \& Turk-Ariss, R. (2009). Bank competition and financial stability. Journal of Financial Services Research, 35(2), 99-118.

Bushman, R. M., Hendricks, B. E., \& Williams, C. D. (2016). Bank competition: Measurement, decision-making, and risk-taking. Journal of Accounting Research, 54(3), 777-826.

Chernykh, L., \& Cole, R. A. (2015, August). How should we measure bank capital adequacy for triggering Prompt Corrective Action? A (simple) proposal. Journal of Financial Stability, 20, 131-143.

Chiaramonte, L., \& Casu, B. (2016). Capital and liquidity ratios and financial distress. Evidence from the European banking industry. The British Accounting Review, 49(2), 138-161.

Chong, T. T.-L., Lu, L., \& Ongena, S. (2013). Does banking competition alleviate or worsen credit constraints faced by small- and medium-sized enterprises? Evidence from China. Journal of Banking \& Finance, 37(9), 3412-3424. 
Cipollini, A., \& Fiordelisi, F. (2012). Economic value, competition and financial distress in the European banking system. Journal of Banking \& Finance, 36(11), 3101-3109.

Craig, B. R., \& Dinger, V. (2013). Deposit market competition, wholesale funding, and bank risk. Journal of Banking \& Finance, 37(9), 3605-3622.

Engineer, M. H., Schure, P., \& Gillis, M. (2013). A positive analysis of deposit insurance provision: Regulatory competition among European union countries. Journal of Financial Stability, 9(4), 530-544.

Fernández, A. I., González, F., \& Suárez, N. (2016). Banking stability, competition, and economic volatility. Journal of Financial Stability, 22(C), 101-120.

Fiordelisi, F., \& Mare, D. S. (2014, July). Competition and financial stability in European cooperative banks. Journal of International Money \& -Finance, 45(C), 116.

Fiordelisi, F., \& Marqués-Ibañez, D. (2013). Is bank default risk systematic? Journal of Banking \& Finance, 37(6), 2000-2010.

Francis, W. B., \& Osborne, M. (2012). Capital requirements and bank behavior in the UK: Are there lessons for international capital standards? Journal of Banking \& Finance, 36(3), pp. 803-816.

Fungácová, Z., \& Weill, L. (2013, March). Does competition influence bank failures? Economics of Transition, 21(2), 301-322.

Fungácová, Z., Solanko, L., \& Weill, L. (2014). Does competition influence the bank lending channel in the euro area? Journal of Banking \& Finance, 49(C), 356-366.

Guidara, A., Lai, V. S., Soumaré, I., \& Tchana, F. T. (2013). Banks' capital buffer, risk and performance in the Canadian banking system: Impact of business cycles and regulatory changes. Journal of Banking \& Finance, 37(9), 3373-3387.

Huang, H.-H., \& Lee, H.-H. (2013). Product market competition and credit risk. Journal of Banking \& Finance, 37(2), 324-340.

Jiang, L., Levine, R., \& Lin, C. (2017, Jan). Does competition affect bank risk? National Bureau of Economic Research, Working Paper No. 23080.

Jiméneza, G., Lopezb, J. A., \& Saurinaa, J. (2013). How does competition affect bank risk-taking? Journal of Financial Stability, 9(2), 185-195.

Jonghe, O. D., \& Öztekin, Ö. (2015). Bank capital management: International evidence. Journal of Financial Intermediation, 24(2), 154-177.

Kaufman, G. G. (2014, Aug). Too big to fail in banking: What does it mean? Journal of Financial Stability, 13(1), 214-223.

Li, J. (2017, January). Accounting for banks, capital regulation and risk-taking. Journal of Banking \& Finance, 74(C), 102-121.

Linsmeier, T. J. (2011). Financial reporting and financial crises: The case for measuring financial instruments at fair value in the financial statements. Accounting Horizons, 25(2), 409-417.

Liu, H., \& Wilson, J. O. (2013). Competition and risk in Japanese banking. The European Journal of Finance, 19(1), 1-18.

Luca, A. C., \& Olivero, M. P. (2012, February). Twin Ccrises in emerging markets: The role of liability dollarization and imperfect competition in banking. Review of Development Economics, 16(1), 72-94.

Mulyaningsih, T., Daly, A., \& Miranti, R. (2015). Foreign participation and banking competition: Evidence from the Indonesian banking industry. Journal of Financial Stability, 19(C), 70-82.

Mwega, F. (2011). The competitiveness and efficiency of the financial services sector in Africa: A case study of Kenya. African Development Review, 23(1), 44-59. 
Noss, J., \& Toffano, P. (2016, January). Estimating the impact of changes in aggregate bank capital requirements on lending and growth during an upswing. Journal of Banking \& Finance, 62(C), 15-27.

Phan, H. T., Anwar, S., Alexander, W. R. J., \& Phan, H. T. M. (2019, November). Competition, efficiency and stability: An empirical study of East Asian commercial banks. The North American Journal of Economics \& Finance, 50(C), 100990.

Poshakwale, S. S., \& Qian, B. (2011, March). Competitiveness and efficiency of the banking sector and economic growth in Egypt. African Development Review, 23(1), 99-120.

Saif-Alyousfi, A. Y. H., Saha, A., \& Md-Rus, R. (2018).The impact of bank competition and concentration on bank risk-taking behavior and stability: Evidence from GCC countries. The North American Journal of Economics \& Finance, 51(1), 100867.

Shim, J. (2013). Bank capital buffer and portfolio risk: The influence of business cycle and revenue diversification. Journal of Banking \& Finance, 37(3), 761-772.

Soedarmonoa, W., Machrouhb, F., \& Tarazic, A. (2013, February). Bank Competition, crisis and risk taking: Evidence from emerging markets in Asia. Journal of International Financial Markets, Institutions \& Money, 23(C), 196-221.

VanHoose, D. (2007). Theories of bank behavior under capital regulation. Journal of Banking \& Finance, 31(12), 3680-3697.

Vazquez, F., \& Federico, P. (2015, December). Bank funding structures and risk: Evidence from the global financial crisis. Journal of Banking \& Finance, 61(C), 114. 